\title{
MENJADI MANUSIA BARU LEWAT LEMBAGA PEMASYARAKATAN
}

\author{
Marviecx Jonath Korlefura \\ Politeknik Ilmu Pemasyarakatan \\ email: Marviecx11@yahoo.com
}

\begin{abstract}
This study aims to provide an explanation of the task of the Correctional Institution as a place to foster lawbreakers or commonly called inmates. The method used in this writing is a qualitative descriptive research method to get an idea of the task of the correctional institution. Inmates who enter the Correctional Institution are built to realize the mistakes made so that there is a sense of remorse arising from the inmates. In addition to realizing the guilt of the inmate is also given provisions before returning to the community so that it is less likely for an inmate to repeat the criminal acts he committed. This is made so that there is a social reintegration between the inmate and the community where he committed the criminal act.
\end{abstract}

Keywords: institutions; inmates; social reintegration

\begin{abstract}
Abstrak
Penelitian ini bertujuan untuk memberikan penjelasan mengenai tugas Lembaga Pemasyarakatan selaku tempat membina para pelanggar hukum atau lazim disebut narapidana. Metode yang digunakan dalam penulisan ini adalah metode penelitian yang bersifat deskriptif kualitatif untuk mendapatkan gambaran mengenai tugas lembaga pemasyarakatan. Narapidana yang masuk kedalam Lembaga Pemasyarakatan dibina untuk menyadari kesalahan yang dilakukan supaya ada rasa penyesalan yang timbul dari narapidana. Selain menyadari kesalahan narapidana juga diberikan bekal sebelum kembali kedalam masyarakat Supaya kecil kemungkinan bagi seorang narapidana untuk mengulangi perbuatan pidana yang dilakukannya. Hal ini dibuat supaya terjadi reintegrasi sosial antara narapidana dengan masyarakat tempat dimana ia melakukan perbuatan pidana.
\end{abstract}

Kata Kunci: lembaga pemsyarkatan; narapidana; reintegrasi sosial 


\section{Pendahuluan}

Melakukan sebuah kesalahan tentu pernah dilakukan setiap orang. Diantara Kesalahan yang dibuat tersebut dapat dikategorikan sebagai perbuatan melanggar hukum. Seseorang yang melakukan perbuatan melawan hukum dikategorikan sebagai perbuatan pidana dan harus berhadapan dengan hukum. Menurut Kitab Undang-Undang Hukum Pidana seseorang yang melakukan perbuatan pidana akan diproses secara hukum mulai dari kepolisian, kejaksaan, pengadilan dan yang terakhir adalah Lembaga Pemasyarakatan dengan mencabut kemerdekaannya untuk sementara waktu tidak berada didalam masyarakat (Karnasudirdja, 1996).

Seseorang yang melakukan perbuatan pidana mengakibatkan hubungan social dengan orang lain didalam masyarakat menjadi rusak. Perbuatan pidana adalah pelanggaran terhadap negara (Wahid, 2010). Hal ini mengakibatkan pandangan orang lain terhadap orang yang melakukan perbuatan pidana menjadi negatif dan tidak jarang orang yang melakukan perbuatan pidana akan dikucilkan didalam masyarakat. Hal ini membuat pengaruh negative bagi orang yang melakukan perbuatan pidana. Karena dalam melaksanakan hukumannya ada kemungkinan seseorang dapat menyadari perbuatannyya dan menjadi lebih baik.

Berdasarkan hal ini Lembaga pemasyarakatan selaku pintu terakhir dalam sistem peradilan pidana adalah lembaga yang bertugas untuk menyadarkan seseorang akan apa yang dilakukannya. Lembaga Pemasyarakatan adalah salah satu lembaga pemerintah di bidang pemasyarakatan (Wulandari, 2016). Lembaga Pemasyarakatan merupakan tahap akhir dari sistem peradilan pidana, yakni terdiri dari 4 (empat) sub-sistem yaitu Kepolisian, Kejaksaan,Pengadilan dan Lembaga Pemasyarakatan (Utami \& Indonesia, 2017).

Lembaga pemasyarakatan merupakan salah satu bagian proses pembinaan narapidana (Firdaus, 2017). Hal itu dilakukan semata-mata untuk memperbaiki hubungan social yang rusak antara seorang narapidana dengan masyarakat. Dengan begitu orang yang melakukan tindak pidana akan kembali diterima didalam masyarakat bilamana ia selesai menjalankan hukumannya.

Selanjutnya artikel ini dibuat untuk memberikan penjelasan kepada masyarakat mengenai tugas dan tanggung jawab Lembaga Pemasyarkatan supaya tidak terjadi kesalahan persepsi didalam masyarakat mengenai tugas Lembaga Pemasyarakatan. Tugas yang dimaksud adalah tugas pembinaan yang diterapkan bagi para pelanggar hukum yang telah memiliki putusan tetap dari pengadilan atau narapidana supaya tidak terdapat kesalahan persepsi masyarakat mengenai Lembaga Pemasyarakatan. Akan tetapi masyarakat juga merasakan ataupun merasa puas terhadap apa yang telah dijalani oleh narapidana. 


\section{Metode Penelitian}

Metode yang digunakan dalam penulisan ini adalah metode penelitian yang bersifat deskriptif kualitatif. Menurut (Nazir, 1988), metode kualitatif itu berakar pada latar alamiah sebagai keutuhan manusia sebagai alat penelitian. Menurut (Rukajat, 2018), pengungkapan makna merupakan hal yang esensial digunakan latar alami sebagai sumber data langsung.

Metode kualitatif yang digunakan dalam penelitian ini bertujuan untuk mendapatkan gambaran mengenai tugas lembaga pemasyarakatan untuk membuat narapidana menyadari kesalahan yang dibuat, tidak mengulangi perbuatannya dan kembali ke masyarakat dengan bekal berupa keterampilan dari pembinaan yang diberikan.

\section{Hasil dan Pembahasan}

\section{Pemasyarakatan sebagai pengganti kepenjaraan}

Pemasyarakatan merupakan suatu kegiatan pembinaan yang dilakukan untuk membina seseorang yang melakukan perbuatan melawan hukum didalam masyarakat. Pembinaan dilakukan apabila seseorang telah berada didalam Lembaga Pemasyarakatan (LAPAS) selaku bagian akhir dari sistem pemidanaan menurut urutan tata peradilan pidana. Urutan tata peradilan pidana apabila seseorang melakukan perbuatan melawan hukum dimulai dari kepolisian dengan proses penyelidikan dan penyidikan, kejaksaan dengan proses melengkapi barang bukti untuk persiapan peradilan, pengadilan dengan tugas menjatuhkan hukuman bagi seseorang, dan yang terakhir adalah pemasyarakatan dengan proses pembinaan untuk nantinya kembali kedalam masyarakat. Sistem ini menggantikan sistem yang dipakai sebelumnya yaitu sistem kepenjaraan dengan maksud membalas dendam terhadap perbuatan yang dilakukan seseorang (Suyatno, 1998).

Pemasyarakatan dilakukan dengan menggunakan sebuah sistem yang berdasarkan pancasila atau dengan kata lain tidak lagi menggunakan kekerasan dalam pelaksanaannya, melainkan mengedepankan nilai-nilai Kemanusiaan sesuai dengan amanat dari pancasila terkhususnya sila kedua. Sistem ini dilakukan secara terpadu mulai dari menyadarkan pelaku tindak pidana tentang kesalahan yang ia lakukan, memperbaiki diri, dan membimbing pelaku tindak pidana agar tidak mengulangi perbuatan tindak pidana yang pernah dilakukannya. Bukan hanya itu, pemasyarakatan juga bertugas untuk memperbaiki hubungan sosial yang rusak karena perbuatan pidana yang dilakukan. Dengan adanya perbaikan hubungan sosial antara korban dan pelaku maka otomatis aka nada ketentraman hati antara kedua belah pihak (Herlina, 2004). Oleh karena itu diharapkan apabila seseorang narapidana selesai menjalankan hukumannya maka ia akan kembali diterima didalam 
masyarakat tanpa ada stigma yang mendalam kepadanya bahwa Ia adalah bekas seorang penjahat (Hadisuprapto, 1997).

Seseorang narapidana yang ditempatkan di LAPAS akan mengikuti serangkaian kegiatan pembinaan, baik pembinaan kerohanian maupun pembinaan keterampilan. Pembinaan kerohanian dilakukan untuk mendekatkan narapidana dengan tuhannya serta meningkatkan keimanan terhadap ajaran agamanya. Sementara pembinaan keterampilan dilakukan sebagai bekal bagi narapidana untuk kembali ke masyarakat dengan perantaraan petugas Balai pemasyarakatan sebagai mediator yang membuat penelitian masyarakat (Riskin \& Westbrook, 1987). Bekal inilah yang nantinya dipakai didalam masyarakat supaya tidak ada pemikiran untuk melakukan lagi sebuah perbuatan pidana.

\section{Pembinaan Keterampilan dan Pembinaan kerohanian}

Pembinaan keterampilan yang diterapkan untuk seorang narapidana dilakukan berdasarkan minat dan bakat yang dimiliki oleh seorang narapidana. Bentuk pembinaan keterampilan yang diterapkan contohnya bidang perbengkelan atau yang berhubungan dengan mesin, listrik, kerajinan tangan, pertukangan, jahit, dan kegiatan lainnya yang bermanfaat bagi narapidana. Kegiatan ini diharapkan dapat dipakai untuk mendatangkan penghasilan supaya tidak terlintas dipemikirannya untuk melakukan perbuatan pidana dan bahkan mencegah orang lain untuk melakukan perbuatan pidana.

Salah satu contoh pembinaan keterampilan yang berhasil diterapkan kepada seorang narapidana sebagai bekal ia kembali ke masyarakat adalah Onco, mantan narapidana LAPAS Kelas IIA Ambon. Onco memiliki usaha perbengkelan di tempat tinggalnya, kecamatan sirimau, Kota Ambon. Sebelumnya Onco masuk ke LAPAS kelas IIA Ambon kasus pemukulan yang mengakibatkan kematian. Ketika didalam LAPAS Onco Mengikuti pembinaan keterampilan bidang perbengkelan. Sekarang ini Onco telah memiliki bengkel sendiri dan bukan hanya itu, Onco juga memiliki 2 orang kariawan.

Inilah yang dimaksud dengan menjadi manusia baru. Ketika sebelumnya Onco senang berkelahi sehingga menimbulkan kerugian bahkan korban, sekarang Onco sudah meninggalkan kebiasaan tersebut dengan mengembangkan usaha yang ada. Bukan hanya itu, apabila ada orang yang bertengkar Onco yang menjadi penengah dan menjelaskan bahwa pertengkaran atau perkelahian itu tidak ada gunanya. Hal itu dikatakan berdasarkan apa yang Onco dapatkan di dalam LAPAS.

Harapan kedepannya akan semakin banyak orang yang seperti Onco. Dengan demikian hal ini dapat menekan angka kejahatan yang terjadi didalam masyarakat maupun Negara Indonesia. Dengan menurunnya angka kejahatan 
maka dari sini akan mengidikasikan keberhasilan sistem pemasyarakatan yang dilakukan oleh LAPAS terhadap seorang narapidana..

\section{Kesimpulan}

Pemasyarakatan pada zaman sekarang ini telah mengalami banyak perubahan. Bentuk pemasyarakatan adalah pembinaan yang dilakukan kepada para pelanggar hukum sebagai bekal kepada pelanggar hukum sebelum kembali ke masyarakat. Hal ini diharapkan supaya setiap narapidana menyadari kesalahannya dan tidak mengulangi perbuatan itu.

Pembinaan yang diterapkan oleh LAPAS harus lebih dikembangkan agar setiap orang yang melakukan tindak pidana dapat sadar supaya dapat menekan angka kejahatan yang terjadi didalam masyarakat.

\section{Bibliografi}

Firdaus, I. (2017). Penempatan Narapidana Teroris di Lembaga Pemasyarakatan. Jurnal Penelitian Hukum P-ISSN, 1410, 5632.

Hadisuprapto, P. (1997). Juvenile Delinquency: Pemahaman dan Penanggulangannya. Bandung: Citra Aditya.

Herlina, A. (2004). Perlindungan Terhadap Anak yang Berhadapan Dengan Hukum, Manual Pelatihan untuk Polisi. Jakarta: POLRI and UNICEF.

Karnasudirdja, E. D. (1996). Beberapa Pedoman pemidanaan dan Pengamatan Narapidana. Jakarta: Bina Aksara.

Nazir, M. (1988). Metode Penelitian. Jakarta: Ghalia Indonesia.

Riskin, L. L., \& Westbrook, J. E. (1987). Dispute resolution and lawyers: 1993 supplement to hardcover edition. West Publishing Company.

Rukajat, A. (2018). Pendekatan Penelitian Kualitatif. Yogyakarta: Deepublish.

Suyatno, G. (1998). Seluk Beluk Pemasyarakatan. BPHN, Departemen Kehakiman R.I.

Utami, P. N., \& Indonesia, H. (2017). Keadilan Bagi Narapidana di Lembaga Pemasyarakatan. J. Penelit. Huk. e-ISSN, 2579, 8561.

Wahid, E. (2010). Keadilan Restoratif dan Peradilan Konvensional dalam Hukum Pidana. Buku Dosen-2009.

Wulandari, S. (2016). Efektifitas Sistem Pembinaan Narapidana Di Lembaga Pemasyarakatan Terhadap Tujuan Pemidanaan. Jurnal Ilmiah Hukum dan Dinamika Masyarakat, 9(2). 